\title{
Berrikuntza prozesuetan irakaslearen rolak duen garrantzia eta eragina: Bizkaiko ikastetxe baten ikerketa kasua
}

\author{
The importance and influence of the teacher's role in innovation processes: \\ Research of a school in Bizkaia-Vizcaya \\ Igor Salterain Alberdi, Alexander Barandiaran Arteaga* \\ Humanitate eta Hezkuntza Zientzien Fakultatea \\ Mondragon Unibertsitatea, Eskoriatza, Gipuzkoa
}

LABURPENA: Ikerlan honetan aztertu dira irakasleen rolean egon diren aldaketen inguruko gakoak, ikastetxe batean egin den berrikuntza prozesuan zehar. Berrikuntza oinarritu da testuinguruan, espazioan, materialean eta lan egiteko moduan eragina izan duen aldaketa batean, eta aldaketa honek irakasleengan nolako eragina duen aztertu da. Irakasleen lan egiteko modua, ebaluazioa, talde lana, koordinazioa, formakuntza eta sentimenduak aldaketa gertatu aurretik eta ondoren aztertu dira, bi momentuak alderatuz. Emaitzek adierazi duten moduan, irakaslea prozesuaren parte sentitzen ez baldin bada eta emandako urratsetan parte hartzen ez baldin badu, prozesuan erresistentziak sortzen dira eta, ondorioz, ez da irakaslearen rola aldatzen. Horrek eragitea dakar berrikuntza gauzatu baino lehen lan egiten zen moduaren gainean.

GAKO-HITZAK: berrikuntza prozesuak, irakaslearen rola, talde lana, ebaluazioa, formazio prozesuak, haur hezkuntza.

ABSTRACT: This study examines the key aspects related to the changes experimented in the role of teachers during the innovation process carried out in a school. This innovation has been based on a change in space, and its impact on teachers has been studied. Before and after the space change different aspects were analysed and compared: the way teachers work, assessment, teamwork, coordination, training, and feelings. The results indicated that if the teacher does not feel part of the process and does not participate in the steps that have been taken, resistance arises in the process, and the role of the teacher does not change. This means there is a need to influence on the way we work before the innovation takes place.

KEYWORDS: methodological innovation, teacher's role, teamwork, team coordination, evaluation, training processes, early childhood education.

\footnotetext{
* Harremanetan jartzeko / Corresponding author: Alexander Barandiaran Arteaga. Mondragon Unibertsitatea. Berrikuntza eta Hezkunta Inklusiboa. Humanitate eta Hezkuntza Zientzien Fakultatea. Dorleta auzoa, z/g (20540 Eskoriatza. Gipuzkoa). abarandiaran@mondragon.edu - https://orcid.org/0000-0002-2991-7010

Nola aipatu / How to cite: Salterain Alberdi, Igor; Barandiaran Arteaga, Alexander (2021). "Berrikuntza prozesuetan irakaslearen rolak duen garrantzia eta eragina: Bizkaiko ikastetxe baten ikerketa kasua». Tantak, 33(1), 107-136. (https://doi.org/10.1387/tantak.22203).

Jasotze-data: 2020/10/30; Onartze-data: 2021/01/19

ISSN 0214-9753 - elSSN 2444-3581 / (C) 2021 UPV/EHU
}

(c) (i) $\Theta$ Lan hau Creative Commons Aitortu-EzKomertziala-LanEratorririkGabe 4.0 Nazioartekoa

lizentzia baten mende dago 
Igor Salterain Alberdi, Alexander Barandiaran Arteaga

\section{SARRERA}

Azken urteotan, ikastetxe askok berrikuntza prozesuak martxan jarrita dituzte eta prozesu hauetan irakasleek rol garrantzitsua jokatzen dute, berak baitira berrikuntzak aurrera eraman behar dituztenak. Prozesu horiek maiz gorabeheratsuak izaten dira, kasu batzuetan ez baita erraza izaten irakasleen rol aldaketa. Interesgarritzat jo dugu rol aldaketa horren inguruan ikertzea, lagungarria izan daitekeelako berrikuntza prozesuan sartu nahian edo sartuta dauden ikastetxeentzako. Bestalde, irakasleen hasierako formakuntzari ekarpen interesgarria egingo liokeela uste dugu.

Lan honetan, ikastetxe batean egindako berrikuntza prozesuan zehar, irakasleen rolean egondako aldaketen gakoak aztertu dira.

\section{AURREKARIAK}

\subsection{Gaur egungo hezkuntzaren erronkak}

Gaur egun, globalizazioaren eraginez, gizartean etengabeko aldaketak eta eraldaketak bizi dira (Teran, 2018). Bere momentuan, gizarte industrialetatik informazioaren gizartera egin genuen jauzi. Salto honek, jarduera ekonomikoaren testuinguruan eta gizartearen funtzionamenduan eragina izan zuen: «La sociedad europea está en transición hacia una nueva forma de sociedad en la que es necesario responder a la necesidad de un amplio conocimiento de base y desarrollar habilidades para la ocupación y la vida económica» (Elboj, 2000, 59. or.). Orain, informazioaren gizarte baten bizi gara eta ezagutzaren gizarte batera goaz. Iraultza teknologiko eta digitalari esker, datuak ekoitzi eta truka ditzakegu, duela urte gutxi batzuk imajinatuko ez genituzkeen bitartekoen bidez (García et al., 2019).

Halako gizarte bati erantzuteko, ez da nahikoa ezagutzaren jabe izatea, ezagutza denon eskuetan baitago. Ezagutza hori errealitate berri honi modu eraginkorrean aurre egiteko erabiltzen jakitea izango da funtsezkoa, helburua norbere kabuz pentsatzeko gai den pertsona eraikitzea bada bederen. Gizartearen beharrak aldatzeak, hezkuntzarenak ere aldatzea dakar (De Martín, 2005). Gizarteari erantzun behar dio hezkuntzak; egungo errealitateko egoerei aurre egingo dien hiritarrak hezi behar ditu eta orain arteko hezkuntza-sistemak ez dio errealitate horri erantzuten. Orain arteko hezkuntza-sistema honek, Xx. mendeko ikasleei zuzendua baitzegoen, edukiak transmititzea izan du helburu, ezagutza helaraztea. Irakasle eta ikasleen arteko harreman bertikal tinkoak izan dira nagusi, hau da aditu-ezjakin harremanak eraiki izan dira.

XXI. mendean, aldiz, hezkuntzak transformazio sozial eta pertsonalean lagundu behar du, hezkuntza bizitza osoko aldaketa-prozesu gisa ulertuz (Elboj, 2000). Ikasleek ezagutza guztia eskura izango dute eta etengabe alda- 
tzen joango den informazioa izango da. Hori horrela izaki, egun zer nolako baliagarritasuna du ezagutza hori transmititze hutsak? Zentzurik edukiko al du ezagutza finko bat emateak, etengabe aldatuz doan gizartean? Estatu zentralista batean, hezkuntza nolakoa izango den pentsatu eta diseinatzen du estatuak, berak kudeatu, administratu eta kontrolatzen du, komunitateen gaitasuna albo batera utziz (Mella, 2003), baina, gaur egun hori behar da?

Informazioaren gizartearen agertoki berri honetan planteatzen diren erronkei aurre egin ahal izateko, hezkuntza-sistemak aldaketa sakonak egin behar ditu bere antolaketan, funtzionamenduan, metodologietan, edukietan eta baita bere helburuetan ere (Coll, 2010). Aldaketa horien funtsean, hezkuntzarekiko ikuspegiari buruzko hausnarketa behar-beharrezkoa izango da.

\subsubsection{Berrikuntza metodologikoak}

Egin beharreko aldaketa sakonaren baitan hezkuntzaren ikuspegi aldaketak irakasleak berrikuntzaren bidea hartzera eraman behar ditu. Askotan erreformak berrikuntzarekin lotu dira baina garrantzitsua da bata eta bestea desberdintzea. Barraza-k (2005) kontzeptu bakoitzaren definizioak egin zituen, bien arteko desberdintasuna zein den ulertzeko. Alde batetik erreformek, hezkuntza sistemako estrukturan aldaketak eta antolakuntza zein helburuetan egokitzapenak egitea berekin ekarri ohi dituzte. Bestetik berrikuntzak, aldaketa zehatzei erreferentzia egiten die, ikuspegi pedagogiko-didaktikotik justifikatuta eta baloratuta egon ohi dira eta hiru alderdi aintzakotzat hartzen ditu: ezezaguna den zerbaiten azaleratzea, zerbait hori nobedadetzat edukitzea eta fenomeno berri horren erakundetzea. Azken finean, Rimari-k (2003) esan bezala, erreformek ez dute eskolako sistemaren kultura benetan aldatzen. Esan daiteke erreformak aldaketaren diskurtsoa direla, eta berrikuntzak, aldiz, aldaketak mugimenduan. Horrengatik guztiagatik, garrantzitsua da definitzea, berrikuntza oro aldaketa bat bada ere, aldaketa oro ez da berritzailea (Pérez, 2016). Rivas-ek (2017) horrela definitzen du berrikuntza:

Una fuerza vital, presente en escuelas, educadores, proyectos y políticas, que es capaz de reconocer las limitaciones de la matriz educativa tradicional y alterarla para el beneficio de los derechos de aprendizaje del siglo XXI de nuestros alumnos. (Rivas, 2017, 20. or.)

Berrikuntza batek ezaugarri desberdinak izan behar ditu ikasketa eta garapen bat gerta dadin. Sánchez-ek eta López-ek (2010) egindako ikerlanean lortutako ondorioetan ondorengoa aipatzen da. Lehenik eta behin, eskolaren ikuspegia eta helburuak argiak izan behar dira eta berrikuntza hau aurrera eramango duten agente guztiak ados egon behar dira eta erabakian parte hartu behar dute. Ondoren, eskolaren kultura guztiz aldatu behar da, ikuspegi indibidualistatik elkarlanera salto eginez. Hezkuntza ezin daiteke 
Igor Salterain Alberdi, Alexander Barandiaran Arteaga

loturik egon informazioa buruz ikastearekin eta oroimen lanak egitearekin, ikaskuntza eta irakaskuntza moduak aldatu behar dira.

Sánchez-ek eta López-ek (2010) azaldutakoarekin jarraituz, kontuan hartu beharreko beste ezaugarri bat erabili beharreko estrategiak izango dira. Garapen instituzionalarekin batera, garapen indibidualari garrantzia eman behar zaio, azken finean ikasleak izan behar dira hezkuntza prozesuaren protagonistak eta beren lana izango da beren identitate propio eraikitzea eta horretarako irakasleek estrategia eta tresna desberdinak eskaini behar dizkiete. Eskainitako tresna eta estrategiez baliatuz, ikasleek beren kabuz ikasketa prozesua antolatzeko eta burutzeko gaitasuna garatu beharko lukete (Fullan eta Langworthy, 2014). Eskolaren egiturari ere garrantzia emango zaio, erabaki guneak banatuz eta erabakiak adostasunaren bitartez hartuz. Azkenik, behaketa eta ebaluazioa erabili beharko dira, prozesuaren nondik norakoak ikusteko eta ondo edo txarto dabilen ondorioztatzeko, horrela moldaketak eta autorregulazioa egin ahal izango dira (Sánchez eta López, 2010).

\subsubsection{Irakasleen arteko talde lana eta Koordinazioa}

Berrikuntza prozesua aurrera eramateko unean ezinbestekoa da talde lana eta koordinazioa egotea. Hori guztia posible izateko eskola-kultura bat egotea beharrezkoa da, Sánchez-ek eta López-ek (2010) zioten, eskolakulturak hezkuntza komunitatea osatzen dutenei jarraitu beharreko pausoak markatzen dizkiela. Komunitatean hedatuta dagoen momentuan, jokaera eta gertaera zehatz batzuk aurreikustea lortzen da eta beste batzuk gertagaitzak bihurtzea. Zentzu horretan eta ez beste batean, egitura bat da: jendeari norabide konkretu batzuetara eta ez beste batzuetara eramaten dituen mekanismo moduan jarduten duena. Beraz, kulturak ordena sozial zehatz bat definitzen du, era batzuen iraunkortasuna edo denbora luzerako konfigurazio sozialak bermatuz.

Berrikuntza prozesuaren barruan, hobekuntzan oinarrituko den eskolakultura baten ezaugarriak zeintzuk diren aipatzean, Louis et al.ek (1996) honako berezitasun hauek azpimarratu zituzten: lan taldeak eratzeko prestutasun eta erraztasunak eta zuzendaritzak hauei emandako autonomia mailaren garrantzia. Aldaketara bideratuta dauden kulturen beste ezaugarrietako bat konfiantza da. Konfiantza ezaugarri sistemiko bat bezala agertzen da, interakzio zehatz baten bitartez sortzen dena eta ez da soilik pertsonen jokaeran edo patroian gelditzen, baizik eta errutinetan eta taldeen eginiko ekintzetan agertzen da (Tschennan-Moran, 2004; Tschennan-Moran eta Hoy, 2000). Konfiantza ezartzen eta zabaltzen den kulturetan, irakasleen arteko talde lana ematen da, ondorioz beren artean bakoitzaren praktiken, jakintzen eta baliabideen elkar trukaketa gertatzen da (Muijs et al., 2004).

Balyer-ek et al.ek (2017) ondorioztatu dute eskolako zuzendariek gaitasuna dutela irakasleak ahalduntzeko eta konfiantza bermatzeko. Honela 
izanik, hauek dira landu ditzaketenak: erabakiak modu partekatuan hartzea sustatzea, haien estatusa hobetzea, eskolak lan egiteko erakargarriagoak egitea, konfiantzan oinarritutako harremanak eraikitzea eta komunikazio eta harreman egokien giroa sortzea. Amenabarro-k eta Navarro-k (2020) irakasleen arteko harremanak duen eragina aztertu dute:

Irakasleen arteko harremanak onak, sanoak eta positiboak izatea onurak dakartzan prozesu bat bezala ikusi behar dugu. Gainera, prozesu bat da, eskolako giroan eta irakasleen ongizatean eragin zuzena duelako. Bi elementu horiek interesgarriak dira eskola aldaketaren ikuspegitik, praktika metodologiko berritzaileak eta eraldaketa pedagogikoak sustatzeko unean, aukera egokiagoen aurrean kokatzen gaituztelako (Amenabarro eta Navarro, 2020, 137. or.)

Irakasleen arteko talde lanak eta lankidetzak, berrikuntza prozesua bide onetik aurrera joatea ahalbidetuko dute. Sánchezek eta Lópezek (2010) Altagracia ikastetxeko berrikuntza prozesuan egin zuten ikerketatik ondorioztatu zuten taldean aniztasun handia egon arren, gai orokorrak banakoaren aurretik jartzeko gaitasun handia zutela irakasleek.

\subsubsection{Ebaluazioa}

Moreno-k (2010) dio ebaluazioak eta kalitateak betidanik lotura estua izan dutela, oso zaila izango baitzen prozesu bat kalitatezkoa dela esatea, prozesu bera ebaluatu gabe. Berrikuntza prozesu bat ematen denean, ezinbestekoa da berau ebaluatzea, Murillo-k eta Kricheskyek (2012) dioten modura, berrikuntza prozesu osoan zehar jarraipen sistema bat ezarrita egon behar da. Beren iritziz ebaluazio formatiboa litzateke aplikagarri, baina berrikuntzaren inplementazioa egiten den momentuan ere ebaluazio sakon bat egin behar da, hobekuntzarako jarritako helburuak bete diren edo ez jakiteko. Esan bezala, prozesuan zehar etengabe hausnartzen egon behar da eta horrela, ezartze pausoa ematen denean jakingo da ezarritako helburuak lortu diren edo ez diren lortu eta hobekuntzarik egon den edo ez.

\subsubsection{Formakuntza}

Esan bezala, etengabe aldatuz doan gizartean bizi gara eta ondorioz, etengabeko berritzea ezinbestekoa da. Irakasleek egoerara moldatzeko, aldatu eta etengabe formatzen egon behar dute. Martínez-en (2019) hitzetan, aldaketen aurrean hau da irakasleak egin behar duena:

Irakasleek etengabeko aldaketen aurrean, ikaste-irakaste prozesuan duten rola berrikusta garrantzitsua da, ikasleen ezaugarriei erantzun eman behar badiete eta jakintzaren gizartearen eskakizunetara ego- 
Igor Salterain Alberdi, Alexander Barandiaran Arteaga

kitzeko prestatu behar badira, beren praxia aldatzeko beharra inguruan hausnartu beharko lukete. Bizi diren testuinguruaren buruz gogoeta egin eta berain lana modu asertibo batean nola egin pentsatu beharko lukete. (Martínez, 2019, 48. orri.)

Rodríguez et al.ek (2017) esan zuten beharrezkoa dela irakasle rol berri bat sortzea, egungo hezkuntza sistemari aurre egingo diona, XXI. mendeari aurre egingo diona eta hezkuntza berri bat eraikiko duena. Irakasleak bizitza osoan zehar izandako bizipenetatik eraiki du bere jakintza: familia, irakasle bezala jasotako formazio espezifikoan eta praktikaren bitartez ere bai. Baina irakasle rol horrek eskatzen dituen konpetentziak izateko, gizartean etengabe sortzen dabilen informazio berria jasotzeko eta teknologia berrien aurrerapenei aurre egiteko, ezinbestekoa da irakasleek etengabeko formakuntza jasotzea. Beraz, etengabeko formakuntza izateko:

Es necesario recuperar, no sólo para los alumnos o las alumnas sino para los o las docentes, la centralidad del aprendizaje, superando y ayudando a los o las docentes a superar las percepciones tradicionales respecto de la enseñanza y el aprendizaje como funciones fijas, encarnadas en sujetos y funciones diferenciadas. La propia formación docente debe pasar a verse desde el punto de vista del aprendizaje y de quienes aprenden, antes que desde la enseñanza y desde la oferta (como lo revela la propia terminología: formación, capacitación, entrenamiento, reciclaje, etc. (Torres, 1999, 99. or.)

Irakasleen formakuntzak hezkuntzaren oinarrian egon behar du, formakuntza eskuratzeko laguntasuna emanez. Bolivar-ek (2004) esan bezala, irakasleen etengabeko formakuntza ezin daiteke lanaren testuingurutik at egon, profesional bezala lanaren testuinguruarekin loturik egon behar du. Horretarako irakasleak tresna desberdinez hornitu behar dira eta formakuntza jasotzeko baliabideak eman behar zaizkie:

El profesorado es un aspecto relevante dentro de la educación de un país, su formación no solo inicial sino continua debe ser apreciada y considerada en los ámbitos correspondientes. Es decir, las autoridades competentes deben revisar constantemente el programa de la formación inicial y los planes de formación continua que existan. En paralelo, el profesorado debe asumir constantemente la importancia de reflexionar constantemente sobre su praxis. (Martínez, 2019, 47. or.)

Esan bezala berrikuntza prozesuak emaitza egokiak izateko, talde lana eta ebaluazioa ezinbestekoak dira, beraz, talde lana eta ebaluazioa egiteko modu egokiak zeintzuk diren jakiteko, beharrezkoa da irakasleek formakuntza izatea. 


\subsection{Irakaslearen jarduna}

Aditzera eman dugunez, gaur egungo ikasteko modua ez da lehenagokoa, informazioa leku askotatik jasotzeko aukera baitago eta horrek ikasteko moduan eragin du. Baina irakaskuntzan irakasleek duten rola kasu askotan ez da aldatu, izan ere informazioa eta jakintza guztia dutenak direla eta beren lana ezagutzaren transmisioa dela uste baitute (Viñals eta Cuenca, 2016). Tradizioz ezagutzen transmititzaile izan dira eta rol horretan eroso sentitu dira, haurrak informazioz bete behar dituztela pentsatuz. Aldiz, Tonucci-k (2012) haurrak edalontzi hutsak ez direla adierazi zuen, umeek jakin badakitela, eta gauza asko gainera, baina dakiten hori zer den ez dakigula zioen.

Haurrak ontzi hutsak direla pentsatzearekin batera, tradizioz haur guztiak berdinak direla esateko joera egon da eta ondorioz haur guztiak berdin tratatuak izan dira. Baina haur bakoitza desberdina da, ezaugarri propioak ditu eta arreta jarri behar zaio bakoitzari. Horretarako, Barandiaran et al.ek (2012) azaldu bezala, irakaslea haurraren bidelaguna izan behar da, bakoitzaren ezaugarriak ezagutu eta bakoitzaren garapenerako testuinguru eta baliabide aproposak eskaini. Hezkuntza eremuan gertatzen diren prozesuak, konplexuak zein dinamikoak dira eta horiek horrela izanda, beharrezkoa da irakaslea profesional gogoetatsu eta autonomoa izatea (Esteve, 2004).

Arroyabe-k (2008) esan bezala, irakasleen jarduna ez da nolanahikoa, irakasleen lana jakintzaren transmisio hutsa egitea baino zabalagoa da, baina ideia hori aurrera eramateko aldaketak egin behar dira eta oraindik irakasleen formazio akademikoan ez da aldaketa hori guztiz eman. Fernandez et al.ek (2013) diote irakaslea lan-munduan sartzen denean, lanbide honekiko duen ikuspuntua aldatu egiten dela, irakasle askok transformazio bat bizitzen dutela lanean hasten direnean eta gertakari horri «errealitateshok» esaten diotela. Horrek, beren buruarekiko segurtasuna galtzear dakar, Eirín et al.ek (2009) dioten bezala, irakasle hasiberriek estres handiagoa izaten dute, beren rol berriaren nortasuna aurkitu behar izaten baitute, giro berri, aldakor eta arrotz batean. Gogoeta gidaturako eta irakaskuntzaikaskuntza prozesuari buruzko eztabaidarako denbora behar izaten dute. Ondorioz, nolako irakaslea izan behar da horri aurre egiteko? Zein ezaugarri eduki behar ditu?

Irakasleek hainbat konpetentzia eta trebetasun behar dituzte, halakorik barik oso zaila baita gaur egun ikasleek beren ikaskuntza prozesuan aurrera egitea. Marchesi-k (2006) honako hauek aipatzen ditu: irakasleek izan beharreko konpetentzia eta baliabideen artean, ikasleekiko komunikazio gaitasuna, ikasleei ikasteko interesa estimulatzeko ahalmena, teknologia berriak txertatzeko gaitasuna, atentzio pertsonalizatuko emateko gaitasuna, gaitasun afektiboa, aniztasunari erantzuna emateko gaitasuna eta taldean lan egiteko gaitasuna. Delval-ek (2013) gaineratzen du, irakaslea eskolako 
zutabe garrantzitsu bat izanik, ezinbestekoa duela zenbait ezaugarri betetzea, hala nola, ikasleak entzuten jakitea, laguntzea, bideratzea, jakin-mina piztea, arrazoibideak orientatzea, ikerketak bideratzea, etab. (Mesonero eta Torío, 1998). Eta hori guztia bereganatu ahal izateko, ez da ahaztu behar, beste edozein lanetan bezala, irakasle batek ere behar-beharrezkoak dituela bere lanarekiko jarrera, pasioa, bokazioa eta ezagutza (Bona, 2015; Williams 2015).

Imbernon-en (2015) esanetan, irakasle bakoitzak bere ADN propioa du. Gaur egun, irakaslearen ADNa unibertsitatean jasotzen den formakuntzaren ondoren sortzen da eta horren barruan irakasle lanbideak, izaera propio eta askea izan beharrean, beste batzuen mendeko lanbidetzat hartzen da. Beste erakunde, administrazio, organismok edota enpresak esaten dutenaren mendean daude. Imbernonek (2015) hori aldatzeko beharra adierazi zuen, ADNaren oinarrizko ezaugarriak jarrera, esperientzia, kultura eta ezagutza izan beharko zirela eta inoren menpeko sentitu gabe irakasleen ahalduntzea eman beharko litzatekeela. Horretarako, ezinbestekoa da haiek berengan sinestea, identitate pedagogiko propioa baitute eta ezagutza pedagogikoa sortzeko gai baitira.

Hik Hasi-k (2018) antolatutako jardunaldietarako prestatutako hezkuntza proposamenean azpimarratzen zen irakasteak, zaintzeak eta hezteak duten garrantziagatik, ezin litekeela edonor izan hezkuntzako profesionala. Beharrezkoak dira gaitasuna, prestutasuna eta prestakuntza. Irakasle Eskolan, Pedagogian, Psikologian eta unibertsitateko beste hainbat ikasketetan, ikasleen sarreran honako arlo hauek balioetsi behar direla: ikasketa-mailaz gain, haurrekin edo nerabeekin aritzeko gaitasuna, jarrera, gizarte hurbilarekiko konpromisoa, enpatia, elkarlana, ardurak hartzeko prestutasuna...

Proposamenaren barruan zehatzago, irakasle batek izan beharreko prestakuntza puntuka azaldu zen (Hik Hasi, 2018):

- Haurren Eskubideetan oinarritutako irakaskuntza.

- Psikopedagogian eta soziopedagogian oinarrizko prestakuntza.

- Metodologia berrietan prestatuta.

- Informazioaren eta Komunikazioen Teknologien arloan ezagutza izatea.

- Curriculuma Euskal Herriko kultura-errealitatean oinarrituta egotea.

- Taldean lan egiteko, egoera berriei erantzuteko eta familiekin eta inguruko komunitatearekin harremanetan aritzeko gaitua egotea.

- Oinarrizko euskara hizkuntza oso doitua, hizkuntza idatzian zein ahozkoan gaitua eta goi mailako erabilera izatea, ezinbestekoa da.

Irakaslearen rolari dagokionez, Delvalek (2013) oso argi dauka irakasleek ez dutela irakasten edo ezagutzak transmititzen, baizik eta ikasleek autonomiaz beren jardunetatik ikas dezaten testuingurua egokitzen dutela. Honekin bat, Imbernonek (2015) zioen, irakasleen arteko lankidetza eskola proiektu bateko ardatzetako bat dela eta horren baitan irakasleek galdera 
berriak planteatu eta erantzuteko gai izan behar dutela, eta dena zalantzan jarri.

\section{METODOLOGIA}

Ikerketa kualitatibo hau, paradigma interpretatiboan kokatzen da eta ikastetxe zehatz baten egoera ulertu nahi da (Santamaría, 2013, 91. or.). Egoera berrikuntza prozesu bat da eta bere baitan ikerketa honek fenomeno bat du jomugan, hain zuzen irakaslearen rola, fenomeno hori ulertzea eta aztertzea izan baita (Ruiz, 2012) gure asmoa. Ikuspegi horretatik ez ditugu irakasleak eta beren testuingurua aldagai solte moduan irudikatu, osotasun moduan baizik (Cotan, 2016). Ikuspegi holistiko horrek eskatu digu gure aztergaia bere testuinguruan kokatzea, horregatik ikerketa honetan irakasleak beren ikastetxeko testuinguru historikoaren eta izan duten errealitatearen arabera aztertu dira.

Kasu azterketa burutu den Bizkaiko ikastetxe horretan ikerketa burutzeak beraiek duten hezkuntza errealitatea sakon ulertzeko balio izan digu (Álvarez eta San Fabián, 2012).

\subsection{Ikerketa galderak eta helburua}

Ikerketa honen helburua, ikastetxe batean abiatu den berrikuntza metodologikoak irakaslearen rolean duen eragina aztertzea izan da. Ikerketa hau berrikuntza martxan jarri baino lehen eta martxan jarri ondoren gauzatu denez, konparaketa egiteko aukera egon da eta ondoren hobekuntza proposamenak egin dira. Beraz, ikerketa honen bitartez, hau izan da lortu nahi izan den xede nagusia: Ikastetxeko 3-6 zikloan izan den berrikuntzak irakasleen rolean izan duen aldaketaren analisia eta hobekuntza proposamena egitea. Helburuak kontuan izanda, honako ikerketa galderak erantzun dira:

- IG1: Zein aldaketa izan da irakaslearen rolean berrikuntza eman denetik?

- Ikaste irakaste prozesuan.

- Lankideekiko harremanean.

- Familiarekiko harremanean.

- Haurrekiko harremanean.

- Ebaluazioan.

- Material, espazio eta denboraren antolakuntzan.

- IG2: Zer ikuspegi edo bizipen (emozio, kezka, sentsazio...) daukate irakasleek rolaren inguruan? Berrikuntza gauzatu baino lehen eta ondoren. 
Igor Salterain Alberdi, Alexander Barandiaran Arteaga

- IG3: Zeintzuk dira berrikuntzaren helburuak lortzea errazten duten faktoreak?

\subsection{Parte-hartzaileen deskribapena}

Ikertu den berrikuntza metodologikoa, Bizkaiko ikastetxe batean burutu da. Euskal Herrian dagoen haur hezkuntza, lehen hezkuntza eta derrigorrezko bigarren hezkuntzako ikastegi kontzertatua da. Kooperatiba gisa antolatuta dago eta beste lau ikastetxerekin batera batxilergoa ikasteko aukera ematen dute, horrela 0-18 bitarteko hezkuntza eskaintza emanez. 85 langile daude ikastetxean lanean eta 1015 ikasle dituzte.

Berrikuntza hau haur hezkuntza etapara bideratua da eta etapa horren barruan bigarren zikloan. Ikastetxeak aurreko urteetan haur hezkuntzako 0-3 zikloan eraldaketa prozesu burutu du eta segida eman nahi izan dio haur hezkuntzako bigarren zikloari.

Eraldaketa prozesuan, eraikin berri bat eraiki da. Irakasleak eta haurrak, ikasgela indibidualetan banatuta egotetik, espazio zabal batera pasatu dira. Horrela, gela bakoitzean irakasle bat eta 20 haur egotetik, espazio zabal berdinean 3 irakasle eta adin bereko 60 haur egotera pasatu dira. Espazio ireki horietan, haurren adin eta beharrei erantzuten dien materiala egokitu da. Bertan haurrak modu autonomo batean eta zirkulazio librean, espazio guztitik mugitzen ahal dira, dagoen materiala esploratuz eta jolastuz. Berrikuntza gauzatu baino lehen zituzten klase indibidualak txokoetan banatuta zeuden eta irakasleak bideratutako ekintzak burutzen zituzten, kasu askotan fitxak erabiliz.

Esan bezala, kasu honetan ikerketa-lan honek aztertu duena 3-6 etapan egindako berrikuntzan irakasleak duen rol aldaketaren analisia izan da. Bertan 9 irakasle daude, 8 emakumezko eta gizonezko, adin bakoitzeko, 3, 4 eta 5 urte alegia, 3 irakasle:

-3 urtekoak:

- Parte hartzailea 1: Ikastetxean denbora gutxi baina irakasle bezala esperientzia asko duen pertsona.

- Parte hartzailea 2: Ikastetxean urte batzuk lanean dabilen pertsona.

- Parte hartzailea 3: Ikastetxean urte batzuk lanean dabilen pertsona, baina adin tarte honetako umeekin urte gutxi.

-4 urtekoak:

- Parte hartzailea 4: Ikastetxean urte asko lanean dabilen pertsona.

- Parte hartzailea 5: Ikastetxean urte asko lanean dabilen pertsona.

- Parte hartzailea 6: Ikastetxean urte batzuk lanean dabilen pertsona. 
-5 urtekoak:

- Parte hartzailea 7: Ikastetxean urte batzuk lanean dabilen pertsona, baina adin tarte honetako umeekin urte gutxi.

- Parte hartzailea 8: Ikastetxean urte batzuk lanean dabilen pertsona, baina adin tarte honetako umeekin urte gutxi.

- Parte hartzailea 9: Ikastetxean urte batzuk lanean dabilen pertsona, baina adin tarte honetako umeekin urte gutxi.

Ikerketa honetan parte hartu dutenen onespen esplizitua jaso da lehenengo elkarrizketak burutu aurretik.

\subsection{Prozedura}

Jarraian, kronograma txiki bat dago, ikerketan jarraitu zaion prozesua irudikatzeko:

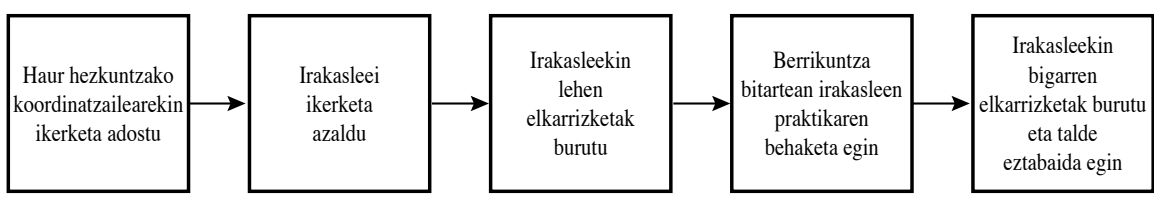

1. irudia

Ikerketa prozesuaren kronograma

\subsection{Datuak jasotzeko teknikak}

Prozesuari erreparatuz antzeman daiteke informazio eta datu mordoa jaso direla, batetik burututako elkarrizketetatik eta talde eztabaidatik, eta bestetik berrikuntza martxan izan denean irakasleen egunerokotasuna aztertzeko egindako behaketetatik eratorriak. Berrikuntza egin baino lehen eta ondoren dokumentazioaren azterketa ere egin da.

Erabili ziren tresnak desberdinak izan ziren lortu nahi izan zenaren arabera, helburu desberdinak izan baitziren tresna bakoitzaren erabilera baldintzatu zutenak.

\subsubsection{Elkarrizketa}

Elkarrizketa erdiegituratuak erabili dira, irakasleen ikuspegia, bizipenak eta esperientziak jasotzeko asmoz, elkarrizketatuaren ikuspuntutik eta beren esperientzian oinarriturik informazioa bilduz (Ballestin eta Fabregues, 2018). Elkarrizketak gertakizunei eta alderdi subjektiboei buruzko 
informazioa biltzea ahalbidetzen du, hala nola, irakasleen egunerokotasuneko lanaren edo jardunaren eta momentu zehatzen (sarrera, zirkulazioa librea, jolas ordua...) inguruko sinesmenak, jarrerak, beldurrak, iritziak, baloreak... beste moduetara ikertu ezin izango direnak (Juaristi, 2003). Bi elkarrizketa burutu dira irakasle bakoitzarekin ikerketa prozesuan zehar, bat berrikuntza gauzatu baino lehen eta bestea ostean. Horrela, irakasleak eraikin berrira joan baino lehen eta ondoren, lan egiteko moduaren inguruan izan dituzten bizipen eta sentimenduak jasotzeko aukera izan dugu eta horrek momentu biak alderatzeko aukera emango digu. Hauek izan dira eginiko bi elkarrizketetan erabilitako galderak:

\section{LEHEN ELKARRIZKETA}

1. Nola ikusten duzue berrikuntza hau?; beharrezkoa da egitea?

2. Nondik dator berrikuntza hau egiteko beharra edo ideia?; komunitate osoak erabakitakoa da?

3. Zein aldaketa egin beharko direla uste duzu?; nola irudikatzen duzu?

4. Zure burua zelan ikusten duzu prozesuan zehar?; eta berrikuntza egiterakoan?

5. Beldur edo kezkak dituzu?

6. Oraingo praktikan zer da egokia eta zer ez?

7. Eta berrikuntzarekin zein gauza ikusten dituzu egoki eta zein ez?

8. Ados zaude guztiarekin edo ez?

9. Irakasle taldea nola ikusten duzu?; eta zuzendaritza taldea?

10. Berrikuntzaren parte sentitzen zara?

11. Prozesu honetan zerbait ikusten duzu faltan?; eta horrela bada, nola egingo zenuke zuk?

\section{BIGARREN ELKARRIZKETA}

1. Eguneko momentu desberdinak aipatuko ditut eta zuk bakoitzean zure lana zein den azaldu:

- Harrera.

- Jolas librea.

- Atsedenaldia.

- Jolas librea.

- Bazkaria.

- Jolas librea.

- Agurra.

2. Zer da momentu bakoitzean egiten duzuna zehazki? Zein irizpideren arabera egiten duzu lan hori, teoria konkretu batetik, formakuntza batetik jasotakoaren arabera...? 
3. Zelan sentitzen zara momentu bakoitzean (momentu bakoitza)?

4. Beldur, kezka edo zalantzarik al duzu? zeintzuk?

5. Zer da aldatu dena zure praktikan? zu zeu aldatu egin zara? zertan? Aldaketa onerako izan dela pentsatzen duzu?

6. Eta zu gustura zaude berrikuntzarekin? zuk zer aldatuko zenuke bizitzen ari zaren egoeratik?

7. Ebaluaziorik egiten duzue? (norena espazioa, umea, irakasleena).

8. Noiz eta zelan? zer aldatuko zenuke ebaluaziotik?

9. Ezezkoa bada, uste al duzu behar dela? zuk nola egingo zenuke zehazki?

10. Irakasleen arteko koordinazio asko ez zegoela irten zen lehen elkarrizketan. Berdin jarraitzen du denak? zer izango litzateke beharrezko koordinazio egoki bat egiteko? zer irizpide erabiliko zenituzke koordinazioa egokia izan dela esateko? zer oztopo ikusten dituzu koordinazio prozesuan?

11. Talde bat zaretela esango zenuke 9 irakasleok? zer irizpide hartzen dituzu kontutan hori esateko? nola bizitzen duzu zuk taldea? zer behar du taldeak garapen gehiago lortzeko?

12. Ikasketa buruarekin harremanik daukazue? nolakoa da? nolakoa izan beharko litzateke zure ustez? zu ikasketa burua bazina zer egingo zenuke?

13. Hemendik aurrera zein da zure erronka pertsonala? Eta berrikuntzaren erronka? ados al zaude erronka horrekin? besteak ere ados daudela uste duzu?

\subsubsection{Behaketa}

Eraikin berrian egin den praktikan behaketa parte-hartzailea burutu da, eta horrek balio izan du irakasleek berrikuntza gertatzen den unean duten rola aztertzeko. Behaketa parte-hartzailean ikertzaile eta parte-hartzaileen arteko interakzioa soziala dago eta datuak modu sistematiko batean jasotzen dira (Taylor eta Bogdan, 1992). Behaketa, berrikuntza garaian egin da, irakasleak lanean egon direnean, espazio bakoitzean goiz baten, momentuko gertakariak jasoz. Juaristi-k (2003) esan bezala, behatzaileak ikusten duena deskribatu behar du balio iritzirik eman gabe, ondoren egiten dira hausnarketak. Behaketa haurrak eskolara sartzen ziren momentutik egin da. Irakasle eta koordinatzaileen arteko batzarrak ere behatu dira. Behaketak egin aurretik behaketa objektu, kasua edo egoera eta modua zehaztu da. 
Behaketako oharrak jasotzeko taula

\begin{tabular}{l|l|l|l|l|l}
\hline Kategoria Eremua & $\begin{array}{c}\text { Haurrarekiko } \\
\text { harremana }\end{array}$ & $\begin{array}{c}\text { Familiarekiko } \\
\text { Harremana }\end{array}$ & Talde lana & Ebaluazioa & $\begin{array}{c}\text { Lan egiteko } \\
\text { modua }\end{array}$ \\
\hline Harrera & & & & & \\
\hline Zirkulazio librea & & & & & \\
\hline Ebaluazioa & & & & & \\
\hline Agurra & & & & & \\
\hline
\end{tabular}

\subsubsection{Eztabaida-taldeak}

Eztabaida-taldeen bidez, parte-hartzaileek beren hitzak erabiliz ikerketa objektuarekiko dituzten sentimendu, kezka eta esperientzien gaineko informazioa lortu nahi izan dugu. Teknika honek, galdera batzuen laguntzaz, parte-hartzaileen arteko komunikaziotik abiatuta, intereseko gai bati buruzko pertzepzioak eta ideiak lortzeko eta informazioa elkarren artean eraikitzeko balio du (Ballestin eta Fabregues, 2018). Berrikuntza honetako partaideen iritziak, ikuspuntuak eta kezkak (berrikuntza prozesua gauzatu ondoren beren jardunaren, ebaluazioaren, talde izaeraren, koordinazioaren eta formakuntzaren ingurukoak) bildu nahi izan dira metodo honekin.

\section{EZTABAIDA-TALDEAK: GIDOIA}

Ondorengo lerroetan talde eztabaidarako erabilitako gidoia azalduko dugu:

Talde eztabaida honetan jasotako informazioa ikerketarako baliagarria denez, baimena eskatzen dizuet ahotsak grabatzeko. Ziurtatzen dizuet grabazio hau ikerketarako soilik erabiliko dela eta anonimotasuna gordeko dela.

\section{[grabagailua martxan jarri]}

Orain arte burututako elkarrizketen harira, orain taldean hitz egiteko aukera izango duzue. Urte batzuk pasatu dira berrikuntza prozesua martxan jarri zela eta orain dela gutxi hasi zarete espazio berrian lan egiten. Horren guztiaren inguruan galdera batzuk egingo dizkizuet. Galderekin hasi baino lehen, esan nahi dizuet, bakoitza libre dela lasaitasun osoz hitz egiteko eta nahi duena esateko askatasun guztiarekin. Eskatzen dudan bakarra txandak errespetatzea da. Hau guztia grabatu egingo denez, ondoren dena ondo ulertzeko. 


\section{GALDERAK}

1. Berrikuntza gauzatu baino lehen, egunerokotasunean nola egiten zenuten lan? Modu berdinean egiten zenuten lan guztiok? zertan berdin eta zertan desberdin? umea ikusteko modua partekatua zenuten? eskaintza berdina zen? zertan oinarritzen zineten zuen eskaintza egiteko? Nola koordinatzen zineten? zein zen koordinatzailearen egitekoa? zein ikasketa buruarena? zuzendaritzarekin zein zen zuen harremana?

2. Eta orain berrikuntza gauzatu dela, zein da zuen jarduna? Modu berdinean egiten duzue lan? galdetu koordinatzaile, ikasketa buru eta zuzendaritzaren inguruan.

3. Zuen arteko harremanetarako eta koordinatzeko zer egiten duzue? (erantzunaren arabera) zer egin beharko litzateke?

4. Egunerokotasunean ebaluaketarik egiten duzue? nola irudikatzen duzue ebaluazioa? zein elementu iruditzen zaizue ebaluatu behar duzuela? Horretarako ba al dago tresnarik? Prozesuak dokumentatzen dituzue? zer esaten diezue familiei euren umeen inguruan? nola egiten duzue? noiz?

5. Formakuntzaren beharra ikusten duzue? zetan zehazki? eta nola nahiko zenukete formazio hori zehazki?

6. Zer uste duzue hobetu beharko zela zuen jardunean? alderdi guztien inguruan galdetu zehazki.

7. Espazio moldatu zenetik, hilabete batzuk pasa dira jada, Nola ikusten duzue zuen burua? Gustura zaudete? seguru sentitzen zarete? baduzue kezka edota beldurrik?

\subsection{Datuak analisia}

Erabilitako tekniketatik lortutako informazioaren analisi kualitatiboa egin da, zehazki edukien analisia (Krippendorff, 1980). Atal honen helburua lortutako informazioari zentzua ematea da (Ballestin eta Fabregues, 2018). Lehen urratsa, lortutako informazio guztia bildu eta elkarrizketen transkripzioa egitea izan da. Dena bilduta izandakoan sakoneko irakurketak egin dira informazio guztiaz egoki jabetu eta barneratzeko. Hau egin ondoren, informazioaren murrizketa bat burutu da, beharrezkoa ez den informazioa alderatuz eta baliagarria dena gordez. Baliagarria zen informazio edo datu guztiak unitateetan sailkatuko dira, irizpiderik desberdinenak aintzat hartuz. Honen ostean, unitateetan kokatu den informazioa kategoria eta azpikategorietan banatu da. Kategoria eta azpikategorietako informazioa erabili da emaitzak eta ondorioak ateratzeko. Kategorizazioa modu irekian burutu da (San Martín, 2014).

Ikerketaren etikarekin lotutako alderdiei dagokienez, azpimarratu behar da oinarrizkoa izan dela, ikerketan parte hartu duten pertsonen duintasuna 
Igor Salterain Alberdi, Alexander Barandiaran Arteaga

eta osotasuna zaintzea eta haien askatasuna eta autonomia errespetatzea. Horrez gain, beren anonimotasuna errespetatzeko, parte hartzaileen bakoitzari $\mathrm{PH}=$ parte hartzailea eta pertsona bakoitzari dagokion zenbakia jarri zaio kode modura.

\section{EMAITZAK}

Datuak jasotzeko erabilitako tekniken bitartez lortutako informazio guztia aztertu ostean, eskuratutako emaitzak azaldu ditugu. Emaitzak ikerketa-galderen arabera antolatuta erakutsiko ditugu. Emaitzetan, behaketetatik, elkarrizketetatik eta talde eztabaidatik lortutako datuak erabili dira. Horretarako behaketatik (B) lortutako erantzunak eta elkarrizketetan eta talde eztabaidan parte-hartzaileen $(\mathrm{PH})$ erantzun laburtuak erabili ditugu.

\subsection{Lehenengo ikerketa-galdera}

Zein aldaketa izan da irakaslearen rolean berrikuntza eman denetik? (Ikaste-irakaste prozesuan, lankideekiko harremanean, familiarekiko harremanean, haurrekiko harremanean, ebaluazioan, material, espazio eta denboraren antolakuntzan).

Irakaslearen rolean berrikuntza eman denetik izan diren aldaketak aztertuz, lehenik eta behin esan dezakegu, lan egiteko moduari dagokionez, gehiengoak aldaketa ikusi duela beren jardunean, bakarka lan egitetik orain taldean lan egitera igaro behar dutelako. Lehen askatasun gehiago zuten bakoitzak nahi zuen erara lan egiteko eta orain berrikuntza metodologikoa eman denean, lan egiterako eran zuten askatasuna murriztu egin da. Baina antzeman daitekeen moduan, taldean lan egin behar badute ere, bakoitzak lan egiteko modu desberdinak ditu:

(B) «Irakasleak desberdinak batzeko momentuan lan egiteko modu desberdina, batek oihukatu bestea modu lasai eta hurbila; Irakasle bat fitxak egiten dagoen bitartean, beste bat zirkulazio librea erabiltzen dago».

Talde lanari dagokionez, datuak alderatuz, 9 irakasleek talde moduan lanik egiten ez dutela ikus daiteke. Horren adibide garbiak dira, esaterako, irakasle batekin adibidez fitxak egitea eta beste batekin zirkulazio librean aritzea. Azpimarratu daitekeen beste gauza bat zera da, urteka harremana badagoela baina etapan ez dela berdina gertatzen. Gerta daiteke teorian bat egitea baina praktika oso desberdinak dituzte

(B) «Irakasle batek tonu altuan oihukatuz batzeko esaten duen bitartean, beste bat haurrengana hurbiltzen da modu lasai eta hurbil batean batu egin behar dela esanez». 
Ebaluazioari dagokionez, ikus dezakegu bi tekniken bitartez lortutako informazioa kontrajarria dela. Irakasle batzuek elkarrizketan esandakoari erreparatuz, esan daiteke ebaluazioren bat egiten dutela edo behintzat, proiektuak amaitzen direnean egiten dutela. Baina behaketaren bitartez lortutako datuek adierazten dute ez dutela inoiz ebaluatzeko tresnarik erabili, ezta inolako oharrik, informaziorik edo apunterik jaso ere.

Formakuntzarekin jarraituz, hasieran aipatutakoa gertatzen da, elkarrizketen bitartez lortutako informazioa kontrajarria da, gehienek formaziorik jaso ez dutela esaten duten arren, badago baten bat formakuntza zabala jaso dutela esaten duena. Formakuntzarik ezaren aurrean, irakasle gehienek honen beharra azpimarratzen dute eta zehazki, «zelan lan egin, nola ebaluatu, nondik nora joan (PH7)» inguruko formakuntza nahi dute.

2. taulan bereizita dauden datuak aztertuz gero, argi gelditzen da irakasle bakoitzak gauzak ikusteko modu oso desberdina duela, gauza berdinaren inguruan ondorio oso desberdinak irten baitira.

\section{2. taula \\ Teknika desberdinetatik lortutako datuen antolaketa}

\begin{tabular}{|c|c|c|}
\hline & Elkarrizketa & Behaketa \\
\hline 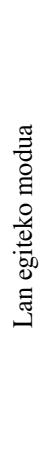 & $\begin{array}{l}\text { 1. Lehen orain baino errazagoa zen, ume } \\
\text { gehiago izan arren, sentsazioa da gutxiago } \\
\text { daudela (PH1). } \\
\text { 2. Lehen bakarkako lana egiten zen eta orain } \\
\text { taldeko lana da eta zaila da (PH4). } \\
\text { 3. Erreferentzia galdu da umeekiko (PH5). } \\
\text { 4. Irakasle batek fitxak erabiltzen dituen bitar- } \\
\text { tean, beste bat zirkulazio librea erabiltzen } \\
\text { dago (PH2). } \\
\text { 5. Lehen bakoitza bere kabuz aritzen zen, } \\
\text { orain taldean lan egin behar dugu hiru ira- } \\
\text { kasleren artean (PH3). }\end{array}$ & $\begin{array}{l}\text { 1. Zigortu egiten da eta epaile la- } \\
\text { nak erabiltzen dira gatazkak bi- } \\
\text { deratzeko (B). } \\
\text { 2. Irakasleek modu desberdinean } \\
\text { jarduten dute. Materiala jaso- } \\
\text { tzeko orduan, batek oihukatu } \\
\text { egiten du eta beste bat modu la- } \\
\text { sai eta hurbilean gerturatzen da } \\
\text { haurrengana (B). }\end{array}$ \\
\hline 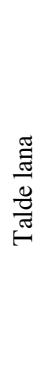 & $\begin{array}{l}\text { 1. Irakasle batek fitxak erabiltzen dituen bitar- } \\
\text { tean, beste bat zirkulazio librea erabiltzen } \\
\text { dago (PH2). } \\
\text { 2. Ez dut uste talde bat garela, urteka harre- } \\
\text { mana dago, etapaka ez (PH2). } \\
\text { 3. Ez gara talde bat (PH3). } \\
\text { 4. Teorian bat egiten dugula pentsatzen dut, } \\
\text { baina praktika desberdinak ditugu (PH1). }\end{array}$ & $\begin{array}{l}\text { 1. Guraso eta haurrak eskolara da- } \\
\text { toz eta ez diote harrerarik egiten. } \\
\text { Irakasle bi beren artean hitz egi- } \\
\text { ten, bestea tailerretan (B). } \\
\text { 2. Irakasle batek tonu altuan oihu- } \\
\text { katuz batzeko esaten duen bitar- } \\
\text { tean, beste bat haurrengana hur- } \\
\text { biltzen da modu lasai eta hurbil } \\
\text { batean batu egin behar dela esa- } \\
\text { nez (B). }\end{array}$ \\
\hline
\end{tabular}


Igor Salterain Alberdi, Alexander Barandiaran Arteaga

\begin{tabular}{|c|c|c|}
\hline & Elkarrizketa & Behaketa \\
\hline 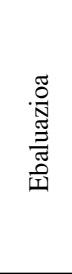 & $\begin{array}{l}\text { 1. Saiatzen gara egiten, baina ez gara hasi } \\
\text { (PH6). } \\
\text { 2. Umearena egiten dugu, baina gurea hasi } \\
\text { beharko gara egiten (PH8). } \\
\text { 3. Ez, normalean ez dugu egiten. Proiektu bat } \\
\text { bukatzerakoan umeak nola egon diren balo- } \\
\text { ratzen da (PH9). }\end{array}$ & $\begin{array}{l}\text { 1. Ez da ebaluatzeko tresnarik era- } \\
\text { bili, ezta inolako informaziorik } \\
\text { jaso (B). }\end{array}$ \\
\hline 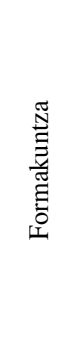 & $\begin{array}{l}\text { 1. Ez dugu formaziorik jaso (PH7). } \\
\text { 2. Formazio asko jaso dugu (PH1). } \\
\text { 3. Ez dugu inolako formaziorik jaso, beste } \\
\text { ikastetxe batzuen kopiatu-itsatsi egin dugu } \\
\text { (PH5). } \\
\text { 4. Formazio beharra daukagu, zelan lan egin, } \\
\text { nola ebaluatu, nondik nora joan... (PH6). } \\
\text { 5. Aldaketa egin baino lehen jaso beharko ge- } \\
\text { nuke (PH4). }\end{array}$ & \\
\hline 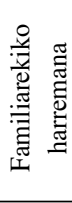 & & $\begin{array}{l}\text { 1. Familia eta haurrak etorri dira } \\
\text { eta ez zaie harrera egin (B). } \\
\text { 2. Agurra egiterako momentuan ez } \\
\text { da gurasoekin inolako kontaktu- } \\
\text { rik egon (B). }\end{array}$ \\
\hline 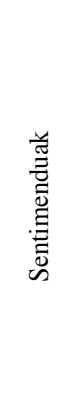 & $\begin{array}{l}\text { 1. Dudak, beldurrek, segurtasun eza, ez jakitea } \\
\text { nondik, nora, zelan? (PH2). } \\
\text { 2. Duda pilo bat dut, eztabaidetan parte har- } \\
\text { tzen dut baina neurri baten, asko neurtu } \\
\text { behar da zer esaten den, zer esaten dugun... } \\
\text { esaten ditut gauzak baina kontrolarekin } \\
\text { (PH7). } \\
\text { 3. Beldur eta kezka asko. Momentu askotan ez } \\
\text { dakit zelan egin behar diren gauzak (PH9). } \\
\text { 4. Oso ondo, bai umeak eta bai gu irabazten ir- } \\
\text { ten garela uste dut (PH1). }\end{array}$ & \\
\hline
\end{tabular}




\subsection{Bigarren ikerketa-galdera}

Zer ikuspegi edo bizipen (emozio, kezka, sentsazio...) daukate irakasleek rolaren inguruan? Berrikuntza gauzatu baino lehen eta ondoren .

\section{Berrikuntza gauzatu baino lehen}

Berrikuntza gauzatu baino lehen, irakasle bakoitzak sentimendu desberdinak zituen, bakoitzak bereak, baina gehien errepikatzen zirenak zalantza, beldurra eta ziurgabetasuna ziren:

«Dudak, beldurrek, segurtasun eza, ez jakitea nondik, nora, zelan? Denok batu behar gara eta hori ez da heldu» (PH2), «Duda pilo bat ditut, eztabaidetan parte hartzen dut baina neurri baten, asko neurtu egin behar da zer esaten den, zer esaten dugun... esaten ditut gauzak baina kontrolarekin, duda asko ditut eta datorren urterako kriston beldurra. Hemen esaten da denok garela bardinak baina ez. Hurrengo urtera begira kriston beldurrarekin nago, gure arteko batzuekin oso ondo funtzionatzen dut baina... baina beldur asko ditut» (PH7), «Orokorrean irakasleek dituzten sentimenduak txarrak dira, ilusioak, poztasunak edo zirrarez beteta egon beharrean, beldurrak eta zalantzak dituzte, etorriko denaren beldur dute eta honek erresistentziak izan daitezke prozesurako» $(\mathrm{PH} 1)$.

\section{Berrikuntza gauzatu ondoren}

Beldurrak eta zalantzak izan arren, espazio berriak umeengan izan duten eragina ikusita pozik daudela esan daiteke. Beldur eta ziurgabetasuna gutxituz joan bada ere, oraindik ezjakintasunaren ondorioz sentimendu hauek mantentzen dira: «Beldur eta kezka asko. Momentu askotan ez dakit zer egin behar dudan» (PH9), «Ba momentu batzuetan ondo eta beste batzuetan txarto» (PH6). Baina esan bezala, umeei begiratu eta berengandik jasotzen dutena ikusita batzuen sentimenduak aldatu egin dira: «Oso ondo, bai umeak eta bai gu irabazten irten garela uste dut» (PH1). 3. taulan ikus daitezke irakasleek emandako erantzunak: 
Igor Salterain Alberdi, Alexander Barandiaran Arteaga

3.taula

«Irakasleen sentimenduak» eremuko kategorizazioa

\begin{tabular}{|c|c|c|c|}
\hline Kategoria & Kodea & Adibidea & \\
\hline \multirow{2}{*}{ 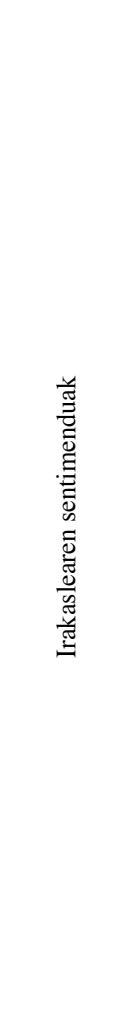 } & $\begin{array}{c}\text { Berrikuntza } \\
\text { metodologikoa } \\
\text { baino lehen }\end{array}$ & BMBL & $\begin{array}{l}\text { 1. Dudak, beldurrek, segurtasun eza, ez jakitea non- } \\
\text { dik, nora, zelan? Denok batu behar gara eta hori } \\
\text { ez da heldu (PH2). } \\
\text { 2. Duda pilo bat dut, eztabaidetan parte hartzen dot. } \\
\text { Baina neurri baten, asko neurtu behar da zer esa- } \\
\text { ten den, zer esaten dugun... esaten ditut gauzak } \\
\text { baina kontrolarekin, duda asko ditut eta datorren } \\
\text { urterako kriston beldurra. Hemen esaten da denok } \\
\text { garela bardinak baina ez. Hurrengo urtera begira } \\
\text { kriston beldurrarekin nago, gure arteko batzuekin } \\
\text { oso ondo funtzionatzen dut baina... baina beldur } \\
\text { asko ditut (PH7). }\end{array}$ \\
\hline & $\begin{array}{c}\text { Berrikuntza } \\
\text { metodologikoaren } \\
\text { ostean }\end{array}$ & BMO & $\begin{array}{l}\text { 1. Oso diferentea da eta niri gehien kostatzen zai- } \\
\text { dana da, bakoitza bere gelan egonda harremana } \\
\text { izatea besteekin. Izan ere, orain } 3 \text { gara eta lehen } \\
\text { zure gelara sartzen zinen, zure umeekin, eta he- } \\
\text { men da «roce continuo». Goizeko bederatzietatik } \\
\text { eta bakoitza gara «de nuestro padre y madre» eta } \\
\text { nik uste dut hor sortzen direla orokorrean rollo } \\
\text { txar-txarrak. Baina bueno, batzuetan arnasa hartu } \\
\text { behar da sakon eta listo (PH5). } \\
\text { 2. Ba momentu batzuetan ondo eta beste batzuetan } \\
\text { txarto (PH4). } \\
\text { 3. Oso ondo, bai umeak eta bai gu irabazten irten } \\
\text { garela uste dut (PH1). } \\
\text { 4. Beldur eta kezka asko. Momentu askotan ez dakit } \\
\text { zer egin behar dudan (PH9). }\end{array}$ \\
\hline
\end{tabular}

\subsection{Hirugarren ikerketa-galdera}

Zeintzuk dira berrikuntzaren helburuak lortzeko gehitzen edo errazten duten faktoreak?

Berrikuntza errazten duten aldagaiak zeintzuk diren jakiteko, prozesuaren helburuak lortzeko zailtasunak edo erresistentziak aztertu ditugu eta hiru aldagai dira berrikuntza prozesua zailtzen duten faktoreak.

Lehenengoa irakasleek taldean lanik ez egitea da. Erabilitako tekniken eta jasotako datuen bitartez, ikus daiteke, irakasleen artean ez dagoela talde lanik. 9 irakasle dira eta ziklo berean egiten dute lan, baina ez dute taldean lan egiten. Bakoitzak lan egiteko modu bat dauka eta nahiz 
eta bileretan hitz egin, gauza komunak izan, bakoitzak berak nahi duen moduan egiten du lan: $" E z$ dut uste talde bat garenik, ondoan ditugunekin bai, urteka uste dut badagoela harremana, baina etapa bezala... egiteko moduak desberdinak dira, nahiz eta berba asko egin publikoan gero bakoitzak nahi duena egiten du. Bileretan hitz egiteko ez dut sentitzen konfiantza bat edo errespetu batekin hitz egiten dela. Denon artean entzun, besteak esandakoarekin ez nago ados... hitz egitea kostatzen da eta «a la defentsiba» dago jendea, hitz egiteko beldurra ere badago» (PH2). Ez daukate elkarrekiko konfiantza eta elkartzen dituen gauzak kontuan hartu eta erabili beharrean, ondokoak zerbait txarto egitearen zain daude, txarto egindako hori hizpidera ekartzeko. Taldean lan egitera ohituta egon behar zuten, urte askoan lanean aritutako irakasleak baitira, baina kontrakoa da, bakoitzak bere lanean modu indibidual eta pertsonalean lan egitera ohitu dira.

Prozesua zailtzen duen bigarren faktorea, ebaluaziorik ez egitea da. Egunerokotasunean ez da ebaluaziorik egiten, irakasleen artean hitz egiten da baina egiten den horrek ez dauka helbururik, ezerezean gelditzen diren hizketaldiak izaten dira. Irakasle gehienek ez dela egiten edo gutxi egiten dela diote eta ez dagoela hau egiteko irizpiderik: "ez da eitten ebaluaketarik»(PH2), «ez dau sistematizaute, ez dau astelehenetan 17:00etan elkartuko gara mailakuek, edo eukingo dot astelehenero ordu erdi nire umien ebaluazioa eitteko»(PH1). Gainera, beren esanetan ez dute argi zer den ebaluatu beharrekoa eta nola egin ebaluaketa: "hombre nik pentsetan dot, zeozer ebaluatzeko lehengo jakin behar dala zein dan helburua eta jakitteko zein dan helburue jakin behar dozu zein dan prozesua eta ez dakigu» (PH6), "Nik pentsetan dot, ebaluaziñue dala hezkuntzako betiko San Benitue. Beti jueten ga ebaluatzera, helburuek argi eukin barik, eta ebaluatzeko irizpide batzuk argi eukitteko, argi eduki behar dozu taldien zelan begittu behar dozun, zer kontutan hartu behar dozun, baina lehengo ipini behar dozu helburua»(PH5). Ebaluazioari garrantzia ematen diete eta gabezia bat dagoela argi daukate baina ez dakite nola egin aurre: «Haur hezkuntzatik urteten dan umiek hori jakin bidau? Ba eztakit» (PH7).

Azkenik, prozesua zailtzen duen aipatu beharreko faktorea formakuntzarik eza da. Berrikuntza abiarazi baino lehen eta ondoren formakuntzarik ez jasotzeagatik kexu dira, guztiek horren beharra azpimarratzen dute. Hainbat hutsune identifikatzen dituzte, landu gabe dauden gai asko eta hau landu ezean prozesuari eta berei (irakasleei) eragin handia egingo diela uste dute: "Uste dut gauza asko lotu behar direla gauza barri bat martxan ipini baino lehen. Zelan lan egingo dugun, nola ebaluatu, nondik nora joango garen, formakuntza jaso behar dugun... eta ikusten dut, eguna helduko dela berrikuntza metodologikoa martxan jartzeko eguna eta txikipark bat izango dela, bakoitzak ahal duena egin edo hobeto ahal duena egingo duela» (PH7). Haurren beharretara egokituko den espazio bat eraikiko du- 
Igor Salterain Alberdi, Alexander Barandiaran Arteaga

tela uste dute, zer nolako espazioa behar duten oso ondo jakin gabe eta honen inguruko formaziorik jaso gabe. Bakoitzak duen jakintzaren araberako espazioa diseinatu dute baina irakasle moduan espazio berri horretarako prest ez daudela diote: «Irakasleok formakuntza behar dugu, dena batera egin behar da, prozesua hasi zenean formakuntza jaso, horrela espazio aldatzeko hitz egiten geundenean (planoen diseinua egiten) hobeto izango zen, horrela jakingo nuen hemen zerbait aldatu behar da, horrela egin behar da... Formakuntza falta dago, espazioa aldatuko da, baina barrukoa (gu), ez gara aldatzen» (PH2).

\section{ONDORIOAK}

Irakasle batek berrikuntza metodologiko batean izan ditzakeen rol aldaketak aztertu dira ikerketa honetan eta alderdi gehienetan aldaketarik egon ez dela ondoriozta daiteke. Izan den aldaketa esanguratsuena, espazio aldaketa egon denez, gela batean irakasle batek bakarrik lan egitetik, espazio handi baten beste bi irakaslerekin lan egitera pasatu direla da. Baina honek ez du beren lan egiteko moduan aldaketa nabarmenik ekarri.

Berrikuntza prozesuak irakasleen rolean duen eragina aztertzeko irakasleen partaidetzari erreparatu zaio. Honela, egindako elkarrizketa eta talde eztabaidan irakasleek esan zuten moduan, berrikuntza prozesua bera ez da haiengandik sortzen den proiektua, ezta ere familiak eskatutakoa. Aldiz, berrikuntza prozesuaren jatorri eta gauzatzea adierazteko inposizio hitza erabili izan dute batzuek. Ikastetxean eta hezkuntza komunitatean parte diren irakasleak kontuan ez hartzeak, hainbat ondorio ekar ditzake, batik bat, irakasleak ahultzea eta prozesuarekiko erresistentziak sortzea (Bolívar, 2000). Hau guztia estatu zentralista batekin alderatu daiteke, non estatuak berak, hezkuntza nolakoa izango den pentsatu eta diseinatu ez ezik, hezkuntza kudeatu, administratu eta kontrolatu egiten baitu, komunitateen gaitasuna albo batera utziz (Mella, 2003). Hobekuntza proposamen bat aurrera joan ahal izateko, hezkuntza komunitate osoaren edo gehiengoaren erabakia izan behar da. Inoiz ez da aldaketarik emango, partaideak ez baldin badute beharrezko ikusten, motibatuta ez baldin badaude eta ez baldin badute aldaketa desio (Murillo eta Krichesky, 2012).

Horrek guztiak lan egiteko moduan eragina izan dezake, Berrikuntza prozesua horrela ulertuz, irakasleek ez dute bere sentitzen eta ez daukate motibaziorik, ondorioz ez dira proiektuan inplikatuko eta iraganean lan egiten zuten bezala lan egiten jarraituko dute. Horregatik, garrantzitsua da irakasleak hasieratik prozesuaren parte sentiaraztea, interesa eta motibazioa sortuz, eta berrikuntzarekin bat datorren lan kultura sortzea (Sánchez eta López, 2010). Hezkuntza komunitatea osatzen duten pertsonen usteak 
eta sineskerak eragin handia izan dezakete berrikuntzaren arrakastan, beraz, oso garrantzitsua da aldaketa eta hobekuntza iraunkorra xede dituen eskola-kultura lortzea (Murillo eta Krichesky, 2012).

Irakasleek beren rola eta prozesuan zehar bizi izan dituzten bizipenei (emozio, kezka, sentsazio...) erreparatuz, argi ikusi da gehiengoak beldurra eta ziurgabetasuna sentitu duela. Ziurgabetasun horren aurrean konfiantza lortzeko, irakasleen arteko harreman ona, sakona eta positiboa izatea lagungarria da, irakasleen arteko harreman estuak onurak dakartza eskolako giroan eta irakaslearen ongizatean (Amenabarro eta Navarro, 2020). Prozesuan zehar, ezjakintasuna eta zalantza izan dira gehien erabilitako hitzak, hasieran espazio berria egon baino lehen ez zekitelako nolakoa izango zen, nola lan egin behar zuten eta espazio berria sortzerakoan lasaiago egon arren zalantzak hor jarraitzen zuten, ez zutelako berrikuntza metodologikoaren ostean lan egiteko moduaren inguruko formaziorik jaso.

Horrez gain, hiru dira berrikuntza prozesua zailtzen duten faktoreak. Lehenengoa irakasleek taldean lanik ez egitea da. Ikerketa honen bitartez, ikus daiteke, 9 irakasleren artean ez dagoela talde lanik. Jasotako datuetan ikus daiteke, berrikuntza gauzatu baino lehen irakasle bakoitzak lan egiteko modu bat duela eta beren arteko koordinaziorik ez dela existitzen. Baina, berrikuntza gauzatu eta gero etapako koordinazioa hobetu bada ere, oraindik taldean lan egiteko eta beren artean harreman positiboak eraikitzeko arazoak daudela ikus daiteke eta hitz egiteko konfiantzarik eza da gehien nabarmentzen dutena. Koordinazio eta harreman falta honek eragin zuzena du prozesuarekin, izan ere, konfiantza ezartzen eta zabaltzen den kulturetan, irakasleen arteko talde lana egiten da; ondorioz beren artean bakoitzaren praktiken, jakintzen eta baliabideen elkar trukaketa gertatzen da (Muijs et al., 2004).

Berrikuntza prozesua zailtzen duen bigarren faktorea, ebaluaziorik ez egitea da. Murillo-k eta Krichesky-ek (2012) dioten bezala, berrikuntza prozesu osoan zehar jarraipen sistema bat ezarrita egon behar da, hau ebaluazio formatiboa izanik. Baina berrikuntzaren inplementazioa egiten den momentuan ere ebaluazio sakon bat egin behar da, hobekuntzarako jarritako helburuak bete diren edo ez jakiteko. Baina emaitzetan ikus daitekeen bezala, prozesuan zehar ez dute ebaluaziorik egiten eta inplementazio momentuan ere ez. Ikerketatik irten den beste kezka bat, hezkuntza komunitatetik kanpo dagoen norbaiten (kanpo agente) laguntza falta izan da. Ebaluazioa barne mailan egin daitekeen zerbait da, baina kanpo agente batek egin dezakeen ebaluazioa ere aberasgarria izaten da, kanpo ikuspegi bat ematen diolako, prozesu osoan zehar egon barik eta kutsatu barik dagoelako (Murillo eta Krichesky, 2012).

Azkenik aipatu beharreko hirugarren faktorea formakuntzarik eza. Berrikuntzaren inplementazioa egin baino lehen eta ondoren formazio ez jasotzearen kexu dira, beren jarduna aurrera eramateko gai ez direla esa- 
ten dute. Honek ere zaildu egin du prozesua, Bolivarrek (2004) esan bezala, irakasleen etengabeko formakuntza ezin daiteke lanaren testuingurutik at egon, profesional bezala lanaren testuinguruarekin lotutakoa izan behar da.

\section{HOBEKUNTZA PROPOSAMENAK}

Azken urte hauetan, gizarteak aldaketa ugari jasan ditu, eta Azkarraga-k (2010) dioen moduan, gaur egungo gizarteak, pertsona motibatua, parte-hartzailea, aplikatua bezain inplikatua, sortzailea, autonomoa, talde lanerako jarrera eta gaitasuna duten pertsonak behar ditu. Eginkizun hori hein handi batean, hezkuntzaren esku dago. Gaur egungo hezkuntza sisteman, berrikuntza eta horri erantzungo dion irakasleen rol aldaketa ezinbestekoak dira, baina horretako prozesu egoki bat ezarri behar da.

Berrikuntza prozesu guztiak desberdinak dira, ikastetxe bakoitza mundu bat izanik, bakoitzean martxan jarri nahi den berrikuntza ere mundu bat izango da. Ikastetxe honetan, prozesua martxan dagoenez eta ezinezkoa denez hasierara bueltatzea, ikerketan zehar identifikatutako gabeziei aurre egiteko formazio saio batzuk proposatu dira eta horretarako, Osinaga eta Ozaeta-k (2012) egindako lana hartu da kontuan. Horrez gain, eskola bakoitzak bere beharrei egokitutako berrikuntza bat diseinatzea garrantzitsua denez, etorkizunean berrikuntza prozesu bat martxan jar dezaketen ikastetxeei lagungarri izan daitekeen proposamen egin zitzaien. Horretarako, Murillo eta Kricheskyk (2012) eginiko lana hartu zen oinarri gisa. Hona hemen proposamen laburtua:

\section{Berrikuntza prozesuak jarraitu beharreko pausuak}

Lehenik eta behin argi eduki behar dena zera da, aldaketa bat ez dela ekintza konkretu bat, prozesu bat da (Coronel, 1996; Bolívar, 2002; Fullan, 2002, apud Murillo eta Krichesky 2012). Aldaketa prozesua honako fase edo etapa hauetan banatzen da:

- Hasiera: pertsona edo talde batek, arrazoiren batengatik, hasiera bat ematen dio aldaketa proiektu edo programa bati eta horretarako diagnostiko bat egiten dute.

- Diagnostikoa: ikastetxeko profesionalek eginiko ikerketa eta hausnarketa sakona.

- Planifikazioa: Jarraitu beharreko pausoen plangintza.

- Inplementazio: Plangintza aurrera eramateko erabaki diren estrategia eta ekintzen inplementazio fasea. 
- Ebaluazioa: prozesuan zehar eman diren pausoen ebaluazioa.

- Instituzionalizazioa/Erakundetzea: Eman den berrikuntza edo aldaketa, ikastetxearen kultura bihurtu denean eta egunerokotasunean gauza normaltzat hartzen denean.

Prozesuaren etapa bakoitza, bere osotasunean prozesu singularrak dira eta bakoitzak dagokion iraupena dauka. Gainera, behin eta berriz errepikatzeko aukera egongo da, hobekuntza bat izan arte. Prozesua ez baita lineala, zirkularra baizik.

\section{Formazio saioak}

Horren guztiaren aurrean, formazio programa bat proposatzen dugu, irakasleen formaziorako metodologia berri baten baitan, eztabaida soziozientifikoan kokatzen dena. Osinaga eta Ozaeta-k (2012) esan bezala, eztabaida soziozientifikoa metodologia berritzailea da eta ez du zerikusirik betiko formazio-paradigmekin, non adituak (eskolaz kanpokoak gehienetan), eskolako irakasleari esaten dion zer eta nola egin behar duen bere irakaskuntzak arrakasta izan dezan.

Irakasleen formazio saioetan erabiliko ziren teknikak autokonfrotazioarena eta autokonfrontazio gurutzatuarena dira. Osinaga eta Ozaetak (2012) egindako lanean azpimarratzen dute autokonfrontazioaren bitartez, irakasleari aukera ematen zaiola bere ikasgelako jarduera bideoz ikusteko, bizi izandakoa berriz bizitzeko eta berari buruz kanpoko laguntzarekin aritzeko. Autokonfrontazioaren metodologia honek eskatzen du: a) trebetasun profesionalen analisia egiteko gaitasuna (errutinen, estrategien eta oztopoen kontzientzia hartzea); eta b) gaitasun profesional horiek eraldatzeko eta birkokatzeko ahalegina eta lana egitea, berrikuntza-programen eta helburuen arabera.

Hiru ezaugarri ditu teknika honek; lehena, autokonfrontazioan gutxienez aktore bat eta formatzaile bat egon behar dira; bat galderak egiteko eta bestea egoera azaltzeko. Bigarrena, aktorearen aztarnak aldez aurretik grabatuak izango dira eta grabaketa hori izango da elkarrizketaren oinarria. Azkenik, helburu partekatua egongo da, aktorearen ekintza deskribatzea eta esplizitatzea aztarna horiek erabiliz.

Formazio saioetan ikerketa honetan lortutako datu eta emaitzak erabil daitezke, baina hala ere, grabaketak egin daitezke, horiek irakasleek beren jarduna aurrez ikusteko baliagarrik baitira. Ez baita berdina kanpoko norbaitek esatea edo bakoitzak ikustea, bakoitzak bere lana ikusten duenean, bere jardunaren inguruko kontzientzia hartzen du. Ondorengo taulan formakuntza jarraituko zuen prozesua azaltzen da: 
4.taula

Irakasleen formazio prozesua

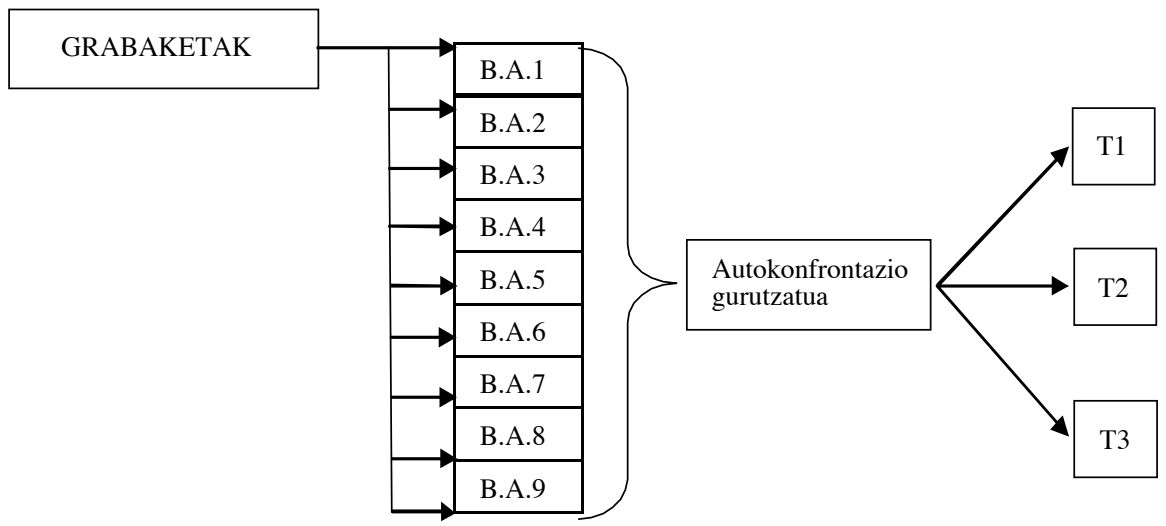

B.A: Bakarkako autokonfrontazioa

T: Tailerrak

Esan bezala lehenik grabaketak egin daitezke eta ondoren irakasle bakoitzak, bakarka autokonfrontazioa egin. Ozaeta-k (2013) horrela definitzen du autokonforntazioa, gaur egun hainbat hurbilbidetan (lanaren psikologia, aktibitatearen analisia, antropologia kognitiboa...) erabiltzen den formazio eta ikerketa teknika da. Teknika horren muina subjektua bere jarduerari edo lanari buruzko irudien aurrean paratzea da. Beste izendapen batzuk ere izan ditu: baliabide estimulatua, erretroakzio bideoa, autokonfrotazio elkarrizketa, autoskopia.... Irakaslea azalpenak ematen dagoen heinean formaziorako lagina lortzeaz gain, bere jardueran inguruko analisia egingo du, izan ditzakeen gabeziak eta hobetu nahi dituenak identifikatuz.

Bakarka egin daitezkeen autokonfrontazioen ostean, autokonfrontazio gurutzatua etor daiteke. Egindako beste saioetatik ateratako informaziotik elikatzen da. Ozaeta-k (2013) dio, autokonfrontazio gurutzatuaren bidez irakasleak egindako jardueraren birjabetzea egiten duela. Bertan konfrontatzen da subjektua, baina ez soilik formatzaile-ikertzailearekin, baita bere berdinkide batzuk ere presente daudela. Harekin batera autokonfrontazio sinplean ikusi duen jarduera bera ikusi eta elkarrizketan sartuko dira.

Eginiko saioen ostean, praktika teoriaz janzteko momentua dator. Osinaga-k eta Ozaeta-k (2012) azaltzen duten bezala, tailerron helburua irakasleen praktika teoriaz hornitzea da, praktika ez baita eraldatzen praktika hutsagatik; izan ere, baina formazio hauetan oinarritzat irakasleen praktika hartzen dugu. Lehen bi tailerretan, irakasleen jardunean eta autokonfrontazioan identifikatutako alderdi desberdinak teoriaz hornitu eta landu daitezke bertan. Ikerketan prozesuari zailtasunak jartzen dizkien identifika- 
tutako faktoreak lantzeko momentua izan daiteke. Formatzaileen lana da, irakasleen jakin-minetik abiatuta, eztabaida eta teoriara bideratzea jakintza. Tailer hauetan landu daitekeena, hauxe izan daiteke:

- Talde lanean nola jardun, eskola-kultura aldatuz.

- Ebaluazioaren garrantziaz jardun, eta ebaluazioa aurrera nola eraman.

- Etengabeko formakuntzaren beharra eta praktikan nola egin.

Azken saioan, arazoari konponbidea emateko jarraitu beharreko urratsak zeintzuk diren ezarriko da. Horretarako irakasleen partetik proposamen bat ekartzea eskatuko litzateke, ondoren denon artean osatuko genukeena.

\section{ERREFERENTZIAK}

Álvarez, C. y San Fabián, J. L. (2012). La elección del estudio de casos en investigación educativa. Gazeta de Antropología, 28(1).

Antúnez, S. (1999). El trabajo en equipo de los profesores y profesoras: factor de calidad, necesidad y problema. El papel de los directivos escolares. Educar, $24,89-110$. or.

Amenabarro, E. eta Navarro, N. Irakasleen arteko harreman pedagogikoak eskola testuinguruan: Jakintza ikastola, begirada berrien bila. Tantak, 32(1), 137163. or.

Arroyave, D. I. (2008). Investigar: una estrategia de actuación para el rol docente actual. Revista Investigaciones en Educación, 7(1), 51-65. or.

Azkarraga, J. (2009). Berandu baino lehen. Erretratuak XXI. mendeari. Alberdania.

Azkarraga, J. (2010). Joseba Azkarraga: Elkarrizketa. Hik Hasi, 154,16-24. or.

Ballestín, B. y Fàbregues, S. (2018). La práctica de la investigación cualitativa en ciencias sociales y de la educación. UOC.

Balyer, A., Ozcan, K., and Yildiz, A. (2017). Teacher empowerment: School administrators' roles. Eurasian Journal of Educational Research, 70, 1-18. or.

Barandiaran, A., Larrea, I. eta Lopez de Arana, E. (2012). Haurren ongizatea II: Hezkuntza proposamenak. Mondragon Unibertsitatea.

Barraza, A. (2005). Una conceptualización comprehensiva de la innovación educativa. Innovación Educativa, 5, 19-31. or.

Bolivar, A. (2000). Los centros educativos como organizaciones que aprenden. Promesas y Realidades. La Muralla.

Bolívar, A. (2004). Formación permanente del profesorado y desarrollo del currículum. Revista Colombiana de Educación, 1, 88-94. or.

Bona, C. (2015). La nueva educación. Los retos y desafios de un maestro de hoy. Plaza y Janes.

Casanova, M. A. (1999). Manual de evaluación educativa. La Muralla.

Coll, C. (2010). Enseñar y aprender en el mundo actual: desafíos y encrucijadas. Pensamiento Iberoamericano, 7, 47-66. or. 
Igor Salterain Alberdi, Alexander Barandiaran Arteaga

Coll, C., Mauri, T. y Onrubia, J. (2006). Análisis y resolución de casos- problema mediante el aprendizaje colaborativo. Revista de Universidad y Sociedad del Conocimiento (RUSC), 3(2), 29-41. or.

Cotán, A. (2016). El sentido de la investigación cualitativa. Escuela abierta, 19, 33-48. or.

De Martín, E. (2005). La formación en centros. Un modelo de formación permanente para equipos docentes. Nau Llibres.

Delval, J. (2013). La escuela para el siglo XXI. Revista Electrónica Sinéctica, 40, $1-18$. or.

Dubet, F. (2006): El declive y las mutaciones de la institución. Revista de Antropología Social, 16, 39-66. or.

Eirín, R., García, H., García y Montero, L. (2009). Profesores principiantes e iniciación profesional. Estudio exploratorio. Profesorado, 3(1), 101-115. or.

Elboj, C. (2000). Educación igualitaria de personas adultas en zonas rurales en la sociedad de la información. Revista de Educación, 322, 59-68. or.

Esteve O. (2004). Nuevas perspectivas en la formación de profesorado de lenguas: hacia el «aprendizaje reflexivo» o «aprender a través de la práctica». In N. Estevan (arg.), Actas I Jornadas Didácticas de Español y Alemán como Lenguas Extranjeras. (8-21. or.). Instituto Cervantes eta Edelsa.

Fernández, L., Martínez-Arbelaiz, A. y Jiménez de Aberasturi, E. (2013). La docencia, una experiencia compartida. Cuadernos de Pedagogía, 436, 58-61. or.

Fullan, M. and Langworthy, M. (2014). A rich seam: How new pedagogies find deep learning. Pearson.

Garcia-Garcia, F. J., López-Francés, I., y Mollá-Esparza, C. (2019). El derecho a la educación en la sociedad del conocimiento: aprender a aprender. Revista Interdisciplinar de Direitos Humanos, 7(1), 191-204. or.

Hik hasi (2018ko martxoak 2). Euskal hezkuntzaren zoru etikoa eta pedagogikoa. http://www.hikhasi.eus/Formazioa/Euskal_hezkuntzaren_zoru_etikoa_eta_ pedagogikoa

Imbernón, F. y Colén, M.T. (2015). Los vaivenes de la formación inicial del profesorado. Una Reforma siempre inacabada. Tendencias Pedagógicas, 25, 57-76. or.

Juaristi, P. (2003). Gizarte ikerketarako teknikak. Teoria eta adibideak. UPV/ EHU.

Krippendorff, K. (1980). Content analysis. Sage.

Louis, K., Marks, H.M. and Kruse, S. (1996). Teachers' professional community in restructuring schools. American Educational Research Journal, 33(4) 757798. or.

Marchesi, A. (2006). El valor de educar a todos en un mundo diverso y desigual. PRELAC, 2. 54-69. or.

Martínez, M. E. (2019). Estudio sobre la formación permanente del profesorado promovida desde la Facultad de Ciencias Económicas y Empresariales de la Universidad Autónoma de Asunción. Doktorego tesia. Universidad de Almería.

Mella, O. (2003). La necesaria reforma de la Reforma Educacional. Umbral 2000, 12.

Mesonero, A. y Torío, S. (1998). Educación Infantil: responsabilidad compartida. In V. Llorent-Bedmar (koord.), Actas del VI Congreso de Educación Comparada. Atención a la infancia y espacios educativos. Aspectos comparados. (495-507. or.). Universidad de Sevilla. 
Monereo, C., Pozo, J. I. (2001). ¿En qué siglo vive la escuela?. Cuadernos de Pedagogía, 298, 50-55. or.

Monereo, C. (2001). Enseñar a aprender. Una vieja aspiración con nuevas coordenadas. $A D E S, 19,25-27$. or.

Moreno, T. (2010). Lo bueno, lo malo y lo feo: las muchas caras de la evaluación. Revista Iberoamericana de Educación Superior. 1(2), 88-101. or.

Muijs, D., Harris, A., Chapman, C., Stoll, L. and Russ, J. (2004). Improving Schools in Socioeconomically Disadvantaged Areas - A Review of Research Evidence. School Effectiveness and School Improvement, 15(2) 149-175. or.

Murillo, F.J. y Krichesky, G. (2012). El Proceso del Cambio Escolar. Una Guía para Impulsar y Sostener la Mejora de las Escuelas. Revista Iberoamericana sobre Calidad, Eficacia y Cambio en Educación, 10(1), 26-43. or.

Osinaga, M. eta Ozaeta, A. (2012). Irakasleen formazioa berritzeko metodologia: autokonfrontazioa. Esperientzia bat Zarauzko Salbatore Mitxelena ikastolan. Jakingarriak, 71, 34-39. or.

Ozaeta, A. (2013). Hizkuntza irakasleen prestakuntzarako eta prestakuntzaren ikerketarako proposamen bat. Ikastaria, 19, 69-95. or.

Pereira, Z. (2011). Los diseños de método mixto en la investigación en educación: una experiencia concreta. Revista Electrónica Educare, 15(1), 15-29. or.

Pérez, J. M. (2016). Educación abierta y educación cerrada. En J. M. Pérez \& S. Tejedor (arg.), Ideas para aprender a aprender: Manual de innovación educativa y tecnología (89-96. Or.). UAB.

Pozo, J. I., Monereo, C. y Castelló, M. (2005). El uso estratégico del conocimiento. In C. Coll, J. Palacios y A. Marchesi (koord.). Desarrollo psicológico y educación 2. Psicología de la educación escolar, (211-234. or). Alianza Editorial.

Rimari, W. (2003). La inovación educativa. Un instrumento de desarrollo. www. eoepsabi.educa.aragon.es

Rivas, A. (2017). Cambio e innovación educativa: las cuestiones cruciales. Santillana.

Rodríguez, G. (2009). Motivación, estrategias de aprendizaje y rendimiento académico de estudiantes de E.S.O. Doktorego tesia. Universidad de A Coruña.

Rodríguez, A. M., Martínez, N., y Raso, F. M. (2017). La formación del profesorado en competencia digital: clave para la educación del siglo XXI. REIDOE, $3(2), 46-65$. or.

Ruiz, J. I. (2012). Metodología de la investigación cualitativa. Universidad de Deusto.

Ruiz-Torres, M. (2014). Estudio de las competencias transversales en un modelo de enseñanza y evaluación formativa en la universidad. Doktorego-tesia. Universidad de Málaga.

Sánchez, M., y López, J. (2010). Culturas institucionales que facilitan y dificultan la mejora de la escuela. Revista de currículum y formación del profesorado. http://www.ugr.es/local/recfpro/rev141ART5.pdf

Sandín, M. P. (2003) Investigación Cualitativa en Educación. Fundamentos y Tradiciones. McGraw-Hill.

Sanfabián, J. L., Belver, J. L. eta Álvarez, C. (2014). ¿Nuevas estrategias y enfoques de aprendizaje en el contexto del Espacio Europeo de Educación Superior? Revista de Docencia Universitaria, 12(4), 249-280. or. 
Sanmarti, N. (2008). 10 ideas clave: evaluar para aprender. Graó.

San Martín, D. (2014). Teoría fundamentada y Atlas.ti: Recursos metodológicos para la investigación educativa. Revista Electrónica de Investigación Educativa, 16 (1), 104-122. or.

Santamaría, J. S. (2013). Paradigmas de investigación educativa: de las leyes subyacentes a la modernidad reflexiva. Entelequia, 16, 91-102. or.

Taylor, S. J. y Bogdan, R. (1992.). Introducción a los métodos cualitativos de investigación. Paidós Básica.

Terán, C. F. (2018). Sociedad del Conocimiento y la Economía. INNOVA, 3(5), 145-154. or.

Torres, M. (1999), Nuevo rol docente: ¿qué modelo de formación, para qué modelo educativo? Perfiles educativos, 82, 99-112. or.

Tschannen-Moran, M. (2004) Trust matters: Leadership for successful schools. Josey-Bass.

Tschannen-Moran, M and Hoy, W.K. (2000). A multidisciplinary analysis of the nature, meaning and measurement of trust. Review of Educational Research, 70, 547-593. or.

Tonucci, F. (2012). Eskolak gutxi batzuentzat izaten jarraitzen du, baina denei eskaintzen zaie. Hik Hasi, 172.

Viñals, A. y Cuenca, J. (2016). El rol del docente en la era digital. Revista Interuniversitaria de Formación del Profesorado, 30(2), 103-114. or. https:// www.redalyc.org/articulo.oa? id=27447325008

Williams, S. (2015). The Future of Principal Preparation and Principal Evaluation: Reflections of the Current Policy Context for School Leaders. Journal of Research on Leadership Education, 10, 222-225. or. 